\title{
MODEL RADA - ČIMBENIK USPJEŠNOSTI PODUKE PLIVANJA
}

\author{
Dražen Rastovski \\ Fakultet za odgojne i obrazovne znanosti, Sveučilište u Osijeku, Republika Hrvatska
}

\begin{abstract}
Sažetak
S ciljem utvrđivanja učinkovitosti pojedinih modela poduke neplivača i njihove usporedbe, testirano je 201 dijete populacije između 9 i 11 godina. Uzorak je podijeljen na dva subuzorka, gdje su djeca učila plivati prema istom programu, ali u različitim modelima rada. Prvi je model bio model poduke neplivača u sklopu ljetovanja i to u trajanju od 14 dana, dok je drugi model proveden u okviru škole u prirodi ali u šest dana. Za utvrđivanje učinkovitosti navedenih modela korišten je statistički programski paket STATISTICA verzija 6.0 (StatSoft Inc., Tulsa, OK, SAD). Normalnost distribucije pojedinih varijabli provjerena je Kolmogorov-Smirnov testom te je utvrđeno da ne slijede istu. Za usporedbu napretka u skupinama korišten je Wilcoxon Matched Pairs Test, a za usporedbu među skupinama Mann-Whitney U Test (za usporedbu inicijalnog i finalnog mjerenja te razlike između finalnog $i$ inicijalnog mjerenja). Kao statistički značajna korištena je vrijednost $P<0,05$. Rezultati dobiveni provedenim istraživanjem pokazali su da oba modela pokazuju dobre rezultate i prigodni su za poduku neplivača. Prednost dajemo modelu 1. odnosno poduci neplivača u okviru ljetovanja. Model 2. poduke neplivača u okviru škole u prirodi radi se u šest dana i očito mu nedostaje vremenskog prostora za još kvalitetniju provedbu. Kako je riječ o programima koji se provode u svim sredinama, neobično je bilo važno utvrditi učinkovitost programa te detektirati uspješnosti pojedinih modela.
\end{abstract}

Ključne riječi: poduka neplivača, ljetovanje, škola u prirodi, modeli rada

\section{UvoD}

Plivanje je jedna od osnovnih ljudskih potreba. Znanje plivanja gotovo je jednako važno kao i znanje hodanja, trčanja, skakanja, a posebice u urgentnim situacijama. Nebrojene su situacije kada znanjem plivanja možemo spasiti svoj ili tuđi život. Plivanje ima sveobuhvatni utjecaj na čovjekov organizam, a posebice u rastu i razvoju djeteta. O utjecaju znanja plivanja na čovjeka govori više autora. „Znanje plivanja, s više aspekata, ima važnu ulogu u suvremenom društvu. Njegove vrijednosti se posebno naglašavaju u odnosu na zdravlje, odgoj i obrazovanje, sport, ekologiju, turizam i sigurnost. Stoga je interes pojedinaca i roditelja za obuku plivanja sve veći, a obveze škole, sporta, lokalne sredine i države sve obvezujuće“ (Mirošević, 2002). „Imajući u vidu pozitivan utjecaj plivanja na svestran i skladan razvoj čovjeka, može se reći da je znanje plivanja za suvremenog čovjeka direktno u funkciji njegovog osposobljavanja i pripreme za život i rad u suvremenom društvu" (Findak, 2002).

Plivanje pozitivno utječe na dišni sustav djeteta. Efekte intenzivnoga plivačkog treninga na plućne volumene, otpore zraka i povezanosti s brzinama prolaska zraka kroz male dišne putove u pretpubertetskom razdoblju kod djevojčica istraživali su Cuurteix, i sur. (1997). Indicije na osnovi rezultata pokazuju da intenzivni plivački trening u pretpubertetu povećava statičke i dinamičke volumene pluća te poboljšava vezu i stanje velikih i malih dišnih putova pa je pretpostavka kako intenzivni plivački trening u to doba potiče rast pluća, usklađeno s razvojem brzine prolaska zraka i alveolarnim plućnim prostorima. 
Plućne i srčane funkcije u trogodišnjem razdoblju kod djece uključene u plivački trening proučavali su i Andrew, i sur. (1972). Usporedbom rezultata plućnih volumena i ekspiracijskog protoka zraka mladih plivača $i$ istodobnih nesportaša pokazalo se da plivači imaju veće plućne volumene kao posljedicu većih vrijednosti vitalnog kapaciteta, pa i veće vrijednosti ekspiracijskog protoka zraka. Navedene vrijednosti bile su očite već na početku istraživanja, a još su veće razlike uočene tijekom trogodišnjeg praćenja. Autori zaključuju da trening u dobi između 8 i 18 godina utječe i na stopu fizičkog rasta i na srčane i plućne funkcije. Isto tako pozitivno utječe i na odgojnu komponentu djeteta jer djeca plivanjem i bavljenjem sportom dobivaju osjećaj sigurnosti i samopouzdanja.

Već od najranije mladosti plivanje i igre na vodi nezaobilazne su aktivnosti u kojima se djeca zabavljaju. Samim tim znanje plivanja je i sociološki fenomen. Da bi se dijete uklopilo s drugom djecom u takvoj igri, mora znati plivati ili se nažalost praviti da zna plivati kako bi bilo prihvaćeno od ostalih. Često takvim ponašanjem dovode sebe i drugu djecu u opasnost od utapanja. Znanje plivanja neophodno je i u svim ostalim aktivnostima u vodi koje se provode bilo kao sport, rekreacija ili kineziterapija.

Plivački sport je sport u kojem se događa vrlo malo ozljeda pa je upravo zbog toga jedan od prvih roditeljskih izbora za djecu (Rastovski i sur., 2011). Isto tako, moguće je relativno dugo uspješno sudjelovanje u vrhunskom sportu. Plivanje nije kontaktni sport i kao takav mnogima odgovara jer su izbjegnute sve grubosti u samom sportu i oko njega. Plivanje je isto tako vrlo čest izbor rekreativaca. Razlog je tomu zasigurno i jednostavan pristup plivalištima, nije potrebna komplicirana i skupa oprema, može se samostalno rekreirati i isto kao i u vrhunskom plivačkom sportu nema ozljeda. Ukoliko u domicilnoj sredini postoji bazen, plivanje je jedan od prvih izbora rekreativaca.

Kod kineziterapije neophodna je i hidroterapija. Brojne su ozlijede i bolesti nakon kojih je u svrhu rehabilitacije indicirano plivanje. To su različita postoperativna stanja, iskrivljenja kralješnice, rehabilitacija nakon lomova, preventiva daljnjem ozljeđivanju i slično. Isto tako, plivanje je za neke invalidne osobe jedini način rekreiranja, a nažalost ponekad i jedina mogućnost kretanja.

Da bi se plivanje moglo koristiti u bilo kojem od navedenih pogleda, ponajprije je važno učenje plivanja odnosno poduka neplivača. Upravo taj dio dječje plivačke edukacije presudan je za daljnje bavljenje tim i svim ostalim sportovima na vodi. Ukoliko dijete pravilno nauči plivati i ako zavoli taj sport, postat će trajna svojina i usmjerit će ga bavljenju tom aktivnošću.

U Republici Hrvatskoj donedavno je bio na snazi i zakon o obvezi osnovnih škola za provođenje poduke neplivača. Zakon je propisivao obvezu škole da dijete do završetka osnovne škole nauči plivati. Doduše, takva obveza za osnovne škole ostala je propisana i kurikulumom za Tjelesnu i zdravstvenu kulturu, odnosno navedena u posebnim zadaćama sata Tjelesne i zdravstvene kulture. Odluka o ukidanju zakona nažalost će zasigurno pogoršati položaj aktivnosti plivanja i sigurnosti djece, ali se isto tako nadamo da će nastavnici i ravnatelji i dalje savjesno provoditi program poduke neplivača koji je propisan planom i programom.

Za sve sudionike procesa poduke neplivača postoji više problema. Nisu sve škole u mogućnosti realizirati program poduke. Istraživanje provedeno na uzorku od ukupno 287 učenica i učenika od 1. do 4. razreda osnovnih škola (Prskalo, 2007) pokazuje kako je $21 \%$ učenika uključeno u izvannastavne, a 64 \% u izvanškolske kineziološke aktivnosti. S obzirom na takve rezultate razvidno je da škola samostalno teško može zadovoljiti potrebe učenika. Modeli koji su prisutni u praksi različiti su, a zajednički im je niz ograničavajućih čimbenika, a to su najčešće financiranje, sama organizacija, problemi needuciranog kadra, i ono što je dugo godina prisutno u tom segmentu edukacije - nedostatak globalnog plana i programa za obuku neplivača koji će biti primjenjiv i provediv u različitim modelima poduke neplivača. Sukladno navedenom, bilo je potrebno izraditi i znanstveno ispitati primjenjivost i učinkovitost novokonstruiranog programa u različitim uvjetima (modelima) rada. 


\section{Problem istražıvanja}

Budući da nisu sva djeca u mogućnosti sudjelovati u organiziranom i stručnom učenju plivanja, (ekonomski, geografski i drugi razlozi) u lokalnoj sredini, škola u prirodi i ljetovanja modeli su pomoću kojih djeca mlađe školske dobi mogu naučiti plivati. Uvidom u Plan i program tjelesne i zdravstvene kulture možemo detektirati osnovni i diferencirani program. Poduka neplivača pripada u osnovni program, dok ljetovanja i škola u prirodi pripadaju u diferencirani. Svi organizacijski oblici rada (osnovni i diferencirani) čine organsku cjelinu i u službi su ostvarivanja cilja i zadaća tjelesnog i zdravstvenog odgojno-obrazovnog područja u širem odnosno tjelesne i zdravstvene kulture u užem smislu (Findak, 1999). Samim time neprocjenjiva je vrijednost programa škole u prirodi i ljetovanja koja pružaju mogućnost stjecanja kompetencija i realizacije posebnih zadaća plana i programa odnosno znanje plivanja. Do sada poduka neplivača provodila se bez plana i programa koji bi bio primjenjiv u različitim modelima rada. Novokonstruirani program razlikuje se od uobičajenih. Njegova primjenjivost u različitim modelima i njegova utemeljenost na učenju igrom zahtijeva širok izbor nastavnih tema i igara. Isto tako, vježbe ronjenja primjenjuju se već u ranoj fazi učenja (od trećeg sata), povezane s vježbama disanja, plutanja, kretanja po vodi klizanjem te rada nogu provedivo različitim elementarnim $\mathrm{i}$ štafetnim igrama. Univerzalni plan i program provediv u više modela rada s jedinstvenim načinom praćenja i vrednovanja doprinijet će boljem uspjehu u poduci neplivača i omogućiti daljnja istraživanja u tom području.

\section{Predmet i cilj istraživanja}

Predmet je provedenog istraživanja novokonstruirani program i njegovi učinci na znanje plivanja provođen u različitim uvjetima - modelima rada (Ijetna škola na moru i bazen u sklopu škole u prirodi) kod djece mlađe školske dobi.

Prvi model provodi se na moru u sklopu ljetne škole i to u trajanju od 20 nastavnih sati raspoređenih u četrnaest dana, dok se drugi model provodi u bazenu istovjetnim programom od 20 nastavnih sati, ali raspoređenih u šest dana tijekom škole u prirodi (koncentrirana nastava).

Osnovni je cilj provedenog istraživanjautvrditi kakvi se učinci mogu postići primjenom programa poduke neplivača te usporediti rezultate dobivenih kod djece koja pohađaju program u različitim uvjetima - modelima rada.

\section{Hipoteze}

S obzirom na definirane probleme, predmet i cilj istraživanja, mogu se postaviti sljedeće osnovne hipoteze:

H1 - djeca koja su učila po modelu 1. ostvarit će značajan napredak u odnosu na inicijalno stanje

H2 - djeca koja su učila po modelu 2. ostvarit će značajan napredak u odnosu na inicijalno stanje

H3 - između dviju grupa u finalnom mjerenju postoji statistički značajna razlika

H4 - ne postoji statistički značajna razlika između modela u napretku od inicijalnih do finalnih stanja 


\section{Metoda}

\section{Uzorak ispitanika}

Uzorak ispitanika sačinjavao je 201 dijete iz populacije neplivača mlađe školske dobi, trećeg razvojnog razdoblja iz Osječko-baranjske županije. Subuzorak od 99 djece provodio je poduku neplivača u moru u sklopu ljetovanja (model 1.), a drugi subuzorak od 102 djece obuku neplivača provodit će u natkrivenom bazenu u sklopu škole u prirodi (model 2.).

Iz populacije izostavljena su djeca oslobođena Tjelesne i zdravstvene kulture zbog zdravstvenih problema. Djeca će biti testirana na početku i kraju provođenja istraživanja.

\section{Uzorak mjernih instrumenata}

Podaci su prikupljeni evidencijom rezultata inicijalnogi finalnog provjeravanja.

Inicijalno i finalno provjeravanje provodilo se na temelju kriterijskih tablica za razinu usvojenosti znanja plivanja.

\section{Način provođenja istraživanja}

Mjerenje je provedeno na dvama radnim mjestima. Prvo mjerenje (model 1.) provedeno je na moru odnosno u sklopu programa ljetovanja u Puli, a drugi (model 2.) u sklopu škole u prirodi u Orahovici i to u natkrivenom bazenu. Praćenje razine usvajanja znanja plivanja bit će provedeno na temelju kriterijskih tablica (Grčić-Zubčević, 1996).

Svi ispitanici za vrijeme mjerenja bili su u odgovarajućoj plivačkoj sportskoj odjeći, bez pomagala. Mjerenje se provodilo na ograđenom kupalištu na moru (model 1.) odnosno u bazenu (model 2.). Mjerenje je provodio autor rada i asistenti (voditelji programa) na radnom mjestu gdje se provodio program. Ekipa mjeritelja unaprijed je bila upoznata s tehnikom mjerenja.

$U$ istraživanju su uzeta samo ona djeca koja su pohađala cjelokupni program.

Kriterij za uspješnost programa bili su: statistički značajan napredak između inicijalnih i finalnih stanja, razlika između finalnih stanja među modelima, napredovanjem za 4 ocjene od inicijalnog stanja (prema Grčić-Zubčević, 1996).

\section{Metode obrade podataka}

Statistička analiza provedena je korištenjem statističkog programskog paketa STATISTICA verzija 6.0 (StatSoft Inc., Tulsa, OK, SAD). Za prikaz distribucije varijabli korištene su tablice frekvencije, uz prikaz karakteristika distribucije uz aritmetičku sredinu (AS), standardnu devijaciju (SD), $95 \%$ raspon pouzdanosti za AS (95\% Cl), medijan (M), interkvartilni raspon (IQR), raspon te koeficijente simetričnosti (skewness) i spljoštenosti (kurtosis) distribucije. Normalnost distribucije pojedinih varijabli provjerena je Kolmogorov-Smirnovim testom. Za usporedbu napretka u skupinama korišten je Wilcoxon Matched Pairs Test, a za usporedbu među skupinama Mann-Whitney $U$ Test (za usporedbu inicijalnog i finalnog mjerenja te razlike između finalnog $i$ inicijalnog mjerenja). Kao statistički značajna korištena je vrijednost $P<0,05$. 


\section{ReZULTATI}

\section{Model 1}

Tablica 1. Frekvencije i postotak ocjena u inicijalnom testiranju

\begin{tabular}{|c|c|c|c|c|}
\hline & N & Kumul. N. & $\%$ - Ocj. & Kumul \% - svi \\
\hline 1 & 7 & 7 & 6,93 & 6,93 \\
\hline 2 & 6 & 13 & 5,94 & 12,90 \\
\hline 3 & 10 & 23 & 9,99 & 22,90 \\
\hline 4 & 47 & 70 & 46,53 & 70,29 \\
\hline 5 & 29 & 99 & 29,71 & 100,00 \\
\hline Nedostaje & 0 & 99 & 0 & 100,00 \\
\hline
\end{tabular}

Legenda: $N$-broj ispitanika prema ocjenama; Kumul. $N$ - kumulativni zbroj ispitanika prema ocjenama; Kumul \% - svi - kumulativni postotak za sve; \% - Ocj. - postotak po ocjenama.

U Tablici 1. prikazan je postotak ocjena iz rezultata inicijalnog provjeravanja. Svi su učenici ocijenjeni na inicijalnom testiranju (100\%). Distribucija ocjena na inicijalnom testiranju kreće se od 1 do 5 koje karakteriziraju neplivače. Najveći postotak ima ocjena 4 (46,53\%), a najmanji ocjena $2(5,94 \%)$.

Tablica 2. Frekvencije i postotak ocjena u finalnom testiranju

\begin{tabular}{|c|c|c|c|c|}
\hline & N & Kumul. N & \% - Ocj. & Kumul. \% - svi \\
\hline 6 & 6 & 6 & 6,06 & 6,06 \\
\hline 7 & 11 & 17 & 11,11 & 17,17 \\
\hline 8 & 7 & 24 & 7,07 & 24,24 \\
\hline 9 & 9 & 33 & 9,09 & 33,33 \\
\hline 10 & 15 & 48 & 15,15 & 48,48 \\
\hline 11 & 51 & 99 & 51,52 & 100,00 \\
\hline Nedostaje & 0 & 99 & 0,00 & 100,00 \\
\hline
\end{tabular}

Legenda: $N$ - broj ispitanika prema ocjenama; Kumul. $N$ - kumulativni zbroj ispitanika prema ocjenama; Kumul \% - svi - kumulativni postotak za sve; \% - Ocj. - postotak po ocjenama.

Nakon provedenog programa i finalnog testiranja, raspon ocjena je od 6 do 11, a najveći postotak čini ocjena 11 (51,52\%). lako se čini da to i nije vrlo visok postotak, ocjena 11 vrlo je zahtjevna i opisuje plivača početnika koji može preplivati 25 metara. Ocjenu 10 koja isto tako opisuje znanje plivanja ali $20-25$ m dobilo je 15 učenika (15,15\%).

Najniža ocjena u finalnom provjeravanju je 6, a zaslužilo je ih 6 učenika $(6,06 \%)$. Ocjena 6 isto tako opisuje učenika koji može preplivati 5 - 7 metara i možemo reći da su svi ipak na neki način naučili osnove. 
Tablica 3. Frekvencije i postotak ocjena, razlike inicijalno - finalno

\begin{tabular}{|c|c|c|c|c|}
\hline & N & Kumul. N & \% - Ocj. & Kumul. \% - svi \\
\hline 2 & 1 & 1 & 1,01 & 1,01 \\
\hline 3 & 7 & 8 & 7,07 & 8,08 \\
\hline 4 & 10 & 18 & 10,10 & 18,18 \\
\hline 5 & 10 & 28 & 10,10 & 28,28 \\
\hline 6 & 37 & 65 & 37,37 & 65,66 \\
\hline 7 & 30 & 95 & 30,30 & 95,96 \\
\hline 8 & 3 & 98 & 3,03 & 98,99 \\
\hline 11 & 1 & 99 & 1,01 & 100,00 \\
\hline Nedostaje & 0 & 99 & 0,00 & 100,00 \\
\hline
\end{tabular}

Legenda: $N$-broj ispitanika prema ocjenama; Kumul. $N$ - kumulativni zbroj ispitanika prema ocjenama; Kumul \% - svi - kumulativni postotak za sve; \% - Ocj. - postotak po ocjenama.

U Tablici 3. prikazan je napredak po ocjenama. Najveći broj, njih 37, napredovalo je za 6 ocjena (37,37 \%), samo jedan za 11 i jedan za 2 (1,01\%) ocjene.

Takvi rezultati pokazuju da su se provedbom programa dobili zadovoljavajući rezultati. Naime, samo 8 učenika nije napredovalo za četiri i više ocjena. Program koji pokazuje napredak za 4 i više ocjena možemo karakterizirati uspješnim (prema Grčić-Zubčević 1996).

Tablica 4. Deskriptivni statistički parametri inicijalno i finalno mjerenje

\begin{tabular}{|c|c|c|c|c|c|c|c|c|}
\hline & N & AS & MED & MIN & MAX & SD. & SKEW & KURT \\
\hline Inicijalno & 99 & 3,85 & 4,0 & 1,00 & 5,0 & 1,15 & $-1,3$ & 1,42 \\
\hline Finalno & 99 & 9,71 & 11,0 & 6,00 & 11,0 & 1,67 & $-1,0$ & $-0,43$ \\
\hline
\end{tabular}

\begin{tabular}{|c|c|c|c|c|c|c|c|c|}
\hline & N & AS & MED & MIN & MAX & SD. & SKEW & KURT \\
\hline Final-Inicij & 99 & 5,86 & 6,00 & 2,00 & 11,0 & 1,41 & $-0,30$ & 1,41 \\
\hline
\end{tabular}

Legenda: $N$-broj djece; $A S$ - aritmetička sredina; SD - standardna devijacija; MIN - minimalna vrijednost; MAX - maksimalna vrijednost; MED - medijan; SKEW - mjera asimetrije distribucije (Skewness); KURT - mjera izduženosti distribucije (Kurtosis)

Normalnost distribucije pojedinih varijabli provjerena je Kolmogorov-Smirnovim testom i utvrđeno je da ne slijede istu. Analizu podataka nastavili smo neparmetrijskim metodama.

Aritmetička sredina ocjena iznosi 3,85 za inicijalno provjeravanje dok za finalno iznosi 9,71. Medijan za inicijalno iznosi 4,0 dok je za finalno 11,0.

Ocjena 4 označava učenika koji ulazi u vodu samostalno, pokušava se održati na vodi u vodoravnom položaju plutanjem ili ronjenjem. Ocjena 10 označava učenika koji može nakon samostalnog ulaska u vodu preplivati bilo kojim načinom, uz disanje, 20 - 25 metara, dok ocjena 11 označava učenika koji nakon skoka na noge u dubokom bazenu prepliva bilo kojim načinom najmanje 25 metara. 
Dražen Rastovski

MODEL RADA - ČIMBENIK USPJEŠNOSTI PODUKE PLIVANJA

Tablica 5. Statistika inicijalno-finalno (Wilcoxonov test parova - utvrđivanje razlike inicijalnih i finalnih stanja unutar modela 1)

\begin{tabular}{|c|c|c|c|c|}
\hline & N & T & Z & p-vrijednost \\
\hline Inicijalno \& Finalno & 99 & 0,00 & 8,638467 & 0,000000 \\
\hline
\end{tabular}

Legenda: $N$-broj djece; $Z$ - vrijednost; $p$ - vrijednost - razina značajnosti

Wilcoxonovim testom parova utvrđeno je da postoji statistički značajna razlika između inicijalnih i finalnih stanja unutar modela $1(Z=8,638 ; p<0,05)$. Takvi rezultati potvrđuju učinkovitost programa.

\section{Model 2}

Tablica 6. Frekvencije i postotak ocjena u inicijalnom testiranju

\begin{tabular}{|c|c|c|c|c|}
\hline & N & Kumul. N & \% - Ocj. & Kumul. \% - svi \\
\hline 2 & 11 & 11 & 10,78 & 10,78 \\
\hline 3 & 35 & 46 & 34,31 & 45,10 \\
\hline 4 & 32 & 78 & 31,37 & 76,47 \\
\hline 5 & 18 & 96 & 17,65 & 94,12 \\
\hline 6 & 3 & 99 & 2,94 & 97,06 \\
\hline 8 & 3 & 102 & 2,94 & 100,00 \\
\hline Nedostaje & 0 & 102 & 0,00 & 100,00 \\
\hline
\end{tabular}

Legenda: $N$ - broj ispitanika prema ocjenama; Kumul. $N$ - kumulativni zbroj ispitanika prema ocjenama; Kumul \% -svi kumulativni postotak za sve; \% - Ocj. - postotak po ocjenama.

U Tablici 6. prikazan je raspon ocjena od 2 do 8. Najveći broj učenika ocijenjen je ocjenom $3(34,31 \%)$ i ocjenom 4 (31,37\%). Takve ocjene karakteriziraju neplivače. Samo je njih troje $(2,94 \%)$ ocijenjeno ocjenom 8 koja karakterizira temeljno znanje plivanja odnosno dijete može preplivati $15-20 \mathrm{~m}$. Njih troje $(2,94 \%)$ dobilo je ocjenu 6 koja opisuje učenika koji može samostalno preplivati $5-7 \mathrm{~m}$.

Tablica 7. Frekvencije i postotak ocjena u finalnom testiranju

\begin{tabular}{|c|r|c|c|c|}
\hline & $\mathrm{N}$ & Kumul. N & \% - Ocj. & Kumul. \% - svi \\
\hline 3 & 4 & 4 & 3,92 & 3,92 \\
\hline 4 & 5 & 9 & 4,90 & 8,82 \\
\hline 5 & 13 & 22 & 12,75 & 21,57 \\
\hline 6 & 4 & 26 & 3,92 & 25,49 \\
\hline 7 & 5 & 31 & 4,90 & 30,39 \\
\hline 8 & 12 & 43 & 11,77 & 42,16 \\
\hline 9 & 7 & 50 & 6,86 & 49,02 \\
\hline 10 & 7 & 57 & 6,86 & 55,88 \\
\hline 11 & 45 & 102 & 44,12 & 100,00 \\
\hline Nedostaje & 0 & 102 & 0,00 & 100,00 \\
\hline
\end{tabular}

Legenda: $N$-broj ispitanika prema ocjenama; Kumul. $N$ - kumulativni zbroj ispitanika prema ocjenama; Kumul \% - svi - kumulativni postotak za sve; \% - Ocj. - postotak po ocjenama. 
Nakon provedenog programa i finalnog testiranja, raspon ocjena je od 3 do 11, a najveći postotak čini ocjena 11 (44,12\%). Najniža ocjena u finalnom provjeravanju je 3 , i to četvero učenika (3,92 \%). Ocjenu od 3 do 5 dobilo je 22 učenika. Njih 13 odnosno (12,75 \%) dobilo je ocjenu 5 koja karakterizira učenika koji može preplivati $2-5 \mathrm{~m}$, a za udah mora spustiti nogu na tlo.

Tablica 8. Frekvencije i postotak ocjena, razlike inicijalno - finalno

\begin{tabular}{|c|r|c|c|c|}
\hline & N & Kumul. N & \% - Ocj. & Kumul. \% - svi \\
\hline 0 & 2 & 2 & 1,96 & 1,96 \\
\hline 1 & 9 & 11 & 8,82 & 10,78 \\
\hline 2 & 12 & 23 & 11,76 & 22,55 \\
\hline 3 & 12 & 35 & 11,76 & 34,31 \\
\hline 4 & 7 & 42 & 6,86 & 41,18 \\
\hline 5 & 12 & 54 & 11,76 & 52,94 \\
\hline 6 & 16 & 70 & 15,69 & 68,63 \\
\hline 7 & 21 & 91 & 20,59 & 89,22 \\
\hline 8 & 6 & 97 & 5,88 & 95,10 \\
\hline 9 & 5 & 102 & 4,90 & 100,00 \\
\hline Nedostaje & 0 & 102 & 0,00 & 100,00 \\
\hline
\end{tabular}

Legenda: $N$ - broj ispitanika prema ocjenama; Kumul. $N$ - kumulativni zbroj ispitanika

U Tablici 8. prikazan je napredak po ocjenama. Najveći pomak od čak devet ocjena ostvarilo je pet učenika ili 4,99 \%, dok je najveći postotak učenika ostvario pomak od sedam ocjena ili 20,59\%. Kao i modelu 1. bilježimo znatan broj učenika koji su se pomaknuli za četiri i više ocjena, ali u ovom modelu njih 35 nije zadovoljilo taj kriterij. Dva učenika $(1,96 \%)$ nije napredovalo u programu.

Tablica 9. Deskriptivni statistički parametri inicijalno i finalno mjerenje

\begin{tabular}{|c|c|c|c|c|c|c|c|c|}
\hline & $\mathrm{N}$ & AS & MED & MIN & MAX & SD. & SKEW & KURT \\
\hline Inicijalno & 102 & 3,79 & 4,0 & 2,00 & 8,0 & 1,23 & 1,12 & 2,32 \\
\hline Finalno & 102 & 8,63 & 10,0 & 3,00 & 11,0 & 2,67 & $-0,70$ & $-0,96$ \\
\hline
\end{tabular}

\begin{tabular}{|c|c|c|c|c|c|c|c|c|}
\hline & N & AS & MED & MIN & MAX & SD. & SKEW & KURT \\
\hline Final-Inicij & 102 & 4,83 & 5,00 & 0 & 9,00 & 2,41 & $-0,21$ & $-1,1$ \\
\hline
\end{tabular}

Legenda: $N$ - broj djece; $A S$ - aritmetička sredina; SD - standardna devijacija; MIN - minimalna vrijednost; MAX - maksimalna vrijednost; MED - medijan; SKEW - mjera asimetrije distribucije (Skewness); KURT - mjera izduženosti distribucije (Kurtosis)

Normalnost distribucije pojedinih varijabli provjerena je Kolmogorov-Smirnovim testom i utvrđeno je da ne slijede istu. Analizu podataka nastavili smo neparametrijskim metodama. Aritmetička sredina na inicijalnom provjeravanju iznosi 3,79 dok na finalnom 8,63. Medijan je 4,0 na inicijalnom dok je na finalnom 10,0. 
Tablica 10. Statistika inicijalno-finalno (Wilcoxonov test parova - utvrđivanje razlike inicijalnih i finalnih stanja unutar modela 2 )

\begin{tabular}{|c|c|c|c|c|}
\hline & N & T & Z & p-vrijednost \\
\hline Inicijalno \& Finalno & 102 & 0,00 & 8,681770 & 0,000000 \\
\hline
\end{tabular}

Legenda: $N$-broj djece; $Z$-zvrijednost; $p$-vrijednost - razina značajnosti

Wilcoxonovim testom parova utvrđeno je da postoji statistički značajna razlika između inicijalnih i finalnih stanja unutar modela $2 .(Z=8,682 ; p<0,05)$. Takvi rezultati potvrđuju učinkovitost programa. Kao i kod modela 1 . uočavamo statistički značajnu razliku između inicijalnih $i$ finalnih stanja u modelu 2.

Tablica 11. Statistika između modela - razlike u inicijalnim i finalnim stanjima između modela (Mann-Whitney U-test)

\begin{tabular}{|c|c|c|c|c|c|c|c|}
\hline & SR & SR & $U$ & Z & p-vrijednost & N1 & N2 \\
\hline Inicijalno & 10705 & 9596,0 & 4343,0 & 1,7124 & 0,0868 & 99 & 102 \\
\hline Finalno & 10942 & 9359,0 & 4106,0 & 2,2872 & 0,0222 & 99 & 102 \\
\hline
\end{tabular}

Legenda: SR - suma rangova, G - grupa, U - rezultat Mann-Whitney U-testa, Z - Z-vrijednost, $N$ - broj djece; p-vrijednost - razina značajnosti

U Tablici 11. prikazane su razlike u inicijalnim stanjima. Nije utvrđena statistički značajna razlika u inicijalnim stanjima među skupinama koje su uključene u model 1. i model 2., dok postoji statistički značajna razlika u finalnim i to u korist modela 1.

Nadalje u finalnom ocjenjivanju uočavamo statistički značajnu razliku u korist modela1. Model 1. provodio se $u$ istom broju nastavnih sati, ali distribuiranih u dva tjedna. $U$ modelu 2. nastava je bila koncentrirana u šest dana.

Tablica 12. Statistika između modela - razlike u napretku u ocjenama između modela (MannWhitney U-test)

\begin{tabular}{|c|c|c|c|c|c|c|c|}
\hline & $\begin{array}{c}\text { SR } \\
\text { G1 }\end{array}$ & $\begin{array}{c}\text { SR } \\
\text { G2 }\end{array}$ & U & Z & p-level & N1 & N2 \\
\hline Final-Inicij & 11128 & 9173 & 3920,0 & 2,7384 & 0,0062 & 99 & 102 \\
\hline
\end{tabular}

Legenda: (SR - suma rangova, G - grupa, U - rezultat Mann-Whitney U-testa, Z - z-vrijednost, N-broj djece)

U Tablici 12. prikazane su razlike u napredku. Utvrđena je statistički značajna razlika u napretku u ocjenama (između inicijalnih i finalnih stanja) među modelima i to u korist modela 1.

Osim što je model 1 . donio bolje rezultate u finalnim stanjima, veći je i statistički značajan napredak u ocjenama 


\section{RASPRAVA}

Rezultati dobiveni inicijalnim testiranjem u modelu 1. (Tablica 1.) pokazuju raspon ocjena od 1 do 5. Takve ocjene karakteriziraju neplivače. Ocjena 1 karakterizira učenika koji ni uz pomoć učitelja ne ulazi u vodu, a bilježimo samo 6,93 \% odnosno sedam učenika. Dijete koje je ocijenjeno ocjenom 1 zasigurno ima veliki problem ili bolje rečeno strah od vode te bi veći broj tako ocijenjene djece otežavao provedbu programa. U ovom slučaju uzorak je bio homogen budući da nije bilo većih odstupanja po ocjenama. Najveći postotak ima ocjena 4 (46,53 \%) koja opisuje dijete koje u vodu ulazi samostalno, pokušava se održati na vodi u vodoravnom položaju plutanjem ili ronjenjem, a ocjenu 5 dobilo je 29 djece (29,71 \%). Ta ocjena (5) karakterizira dijete koje se može dva do pet metara samostalno kretati po vodi, ali za udah mora spustiti noge na tlo. Kao što je vidljivo iz opisa ocjena, takav stupanj usvojenosti znanja plivanja karakterizira zadržavanje daha odnosno nepravilnog disanja. Samim zadržavanjem daha povećava se plovnost i na taj se način dijete može neko vrijeme održavati na vodi ili, pak, donekle kretati. Koliko će se moći kretati, ovisi i o njegovom vitalnom kapacitetu. Poznata je povezanost vitalnog kapaciteta s plivanjem na kraće dionice (Kapus, i sur., 1981; Volčanšek, 1990; Grčić-Zubčević, 1990). Poduku neplivača, između ostalog, započeli smo vježbama disanja kako bi pravilnim disanjem naučili kontrolirati plovnost tijela. Isto tako, program je konstruiran na način da se u ranoj fazi uvode vježbe ronjenja što pomaže u učenju pravilnog disanja. Karakteristika je tog programa i uporaba što više igara kojima djeca mogu sintetizirati vježbe disanja, ronjenja, plutanja i kretanja po vodi već u ranoj fazi programa.

Nakon provedenog programa i finalnog provjeravanja u modelu 1. (Tablica 2.), raspon je ocjena od 6 do 11. Navedene ocjene karakteriziraju razinu usvojenosti znanja plivanja kada učenik može preplivati određenu dionicu bez doticanja podloge. Raspon se kreće od 5 do7 m (ocjena 6) i 25 m (ocjena 11). Najveći postotak čini ocjena 11 (51,51\%). Postotak se možda i ne čini tako velik, ali ocjena 11 vrlo je zahtjevna i iziskuje preplivanih 25 metara nakon skoka na noge. Ocjena 10 također opisuje znanje plivanja ali $20-25 \mathrm{~m}$. Samostalnim ulaskom u vodu dobilo je 15 učenika (15,15\%).

Iz Tablice 3. je vidljiv napredak po ocjenama. Najveći broj, njih 37 je napredovalo za 6 ocjena (37,37 \%), samo jedan za 11 i jedan za 2 (1,01\%) ocjene.

Dobiveni rezultati pokazuju da su se provedbom programa dobili zadovoljavajući rezultati. Naime, samo osam učenika nije napredovalo za četiri i više ocjena. Program kojim se ostvari napredak za četiri i više ocjena možemo karakterizirati uspješnim (prema Grčić-Zubčević, 1996).

Deskriptivni statistički parametri za model 1. prikazani su u Tablici 4. Normalnost distribucije pojedinih varijabli provjerena je Kolmogorov-Smirnovim testom i utvrđeno je da ne slijede istu. Analizu podataka nastavili smo neparametrijskim metodama. Aritmetička sredina na inicijalnom provjeravanju iznosi 3,85 dok na finalnom 9,71. Medijan je 4,0 na inicijalnom dok je na finalnom 11,0.

Tablica 5. prikazuje kako je Wilcoxonovim testom parova utvrđeno je da postoji statistički značajna razlika između inicijalnih i finalnih stanja unutar modela $1(Z=8,638 ; p<0,05)$. Takvi rezultati potvrđuju učinkovitost programa. Iste rezultate dobili su i drugi autori (GrčićZubčević, 1996; Jurak, 1999; Vuković i Trivun, 2002)te su dobiveni rezultati bili očekivani.

Iz Tablice6., koja prikazuje rezultate inicijalnog provjeravanja u modelu 2., vidljiv je raspon ocjena od 2 do 8 . Najveći broj učenika ocijenjen je ocjenom $3(34,31 \%)$ i ocjenom 4 $(31,37 \%)$. Takve ocjene karakteriziraju neplivače. Samo je njih troje $(2,94 \%)$ ocijenjeno ocjenom 8 koja karakterizira temeljno znanje plivanja odnosno dijete može preplivati $15-20 \mathrm{~m}$. Njih $3(2,94 \%)$ dobilo je ocjenu 6 koja opisuje učenika koji može samostalno preplivati $5-7 \mathrm{~m}$. Kao i kod modela 1. najveći postotak učenika ocijenjen je ocjenom koja karakterizira neplivača i to nešto nižom ocjenom nego u modelu 1 . Ocjena 3 karakterizira razinu znanja kada dijete u vodu 
ulazi samostalno, ali se ne usuđuje ni u jednom trenutku podignuti obje noge s podloge, za razliku od ocjene 4 (najveći postotak u modelu 1.) kada se učenik pokušava održati na vodi u vodoravnom položaju plutanjem ili ronjenjem.

Nakon provedenog programa i finalnog testiranja (Tablica 7.) raspon je ocjena u modelu 2. od 3 do 11, a najveći postotak čini ocjena 11 (44,11\%). Najniža ocjena u finalnom provjeravanju je 3, i to četvero učenika (3,92\%). Ocjenu od 3 do 5 dobilo je 22 učenika. Njih 13 odnosno $(12,74 \%)$ dobilo je ocjenu 5 koja karakterizira učenika koji može preplivati $2-5 \mathrm{~m}$, a za udah mora spustiti nogu na tlo. Gledajući po postotcima ocjena, možemo zaključiti da je model 2. ostvario nešto lošije rezultate.

Iz Tablice 8. vidljiv je napredak po ocjenama. Najveći pomak od čak devet ocjena ostvarilo je pet učenika ili 4,99\%, dok je najveći postotak učenika ostvario pomak od sedam ocjena ili $20,59 \%$. Kao i modelu 1. bilježimo znatan broj učenika koji su se pomaknuli za četiri i više ocjena, ali u ovom modelu njih 35 nije zadovoljilo taj kriterij. Dva učenika (1,96 \%) nije napredovalo u programu.

Kao i modelu 1. bilježimo znatan broj učenika koji su se pomaknuli za četiri i više ocjena, ali u ovom modelu njih 35 nije zadovoljilo taj kriterij.

Normalnost distribucije pojedinih varijabli (Tablica 9.) u modelu 2. provjerena je Kolmogorov-Smirnovim testom i utvrđeno je da ne slijede istu. Analizu podataka nastavili smo neparametrijskim metodama. Aritmetička sredina na inicijalnom provjeravanju iznosi 3,79 dok na finalnom 8,63. Medijan je 4,0 na inicijalnom dok je na finalnom 10,0.

Wilcoxonovim testom parova (Tablica 10.) utvrđeno je da postoji statistički značajna razlika između inicijalnih i finalnih stanja unutar modela 2 . $(Z=8,682 ; p<0,05)$. Takvi rezultati potvrđuju učinkovitost programa.

\section{Razlike između modela}

Iz Tablice 11. vidljivo je da nije utvrđena statistički značajna razlika u inicijalnim stanjima među skupinama koje su uključene u model 1 . i model 2 . Možemo zaključiti da učenici pripadaju istoj populaciji.

Nadalje, u finalnom ocjenjivanju uočavamo statistički značajnu razliku u korist modela 1. Model 1. provodio se $u$ istom broju nastavnih sati, ali distribuiranih u dva tjedna. $U$ modelu 2. nastava je bila koncentrirana u šest dana. Očito da je ipak duži „,boravak“ u programu donio i bolje rezultate. Slične rezultate dobili su i Okičić, T. i sur. (2008) koji su utvrdili prednost višednevne nastave u odnosu na koncentriranu u nekoliko dana. Model ljetovanja osim programa obuke neplivača ima i drugih sadržaja koji su zacijelo poboljšali rezultat (kupanje u slobodno vrijeme i sl.). Osim toga, za razliku od koncentrirane nastave u modelu višednevne nastave daje se prostor djetetu za oporavak u fiziološkom i emocionalnom smislu, ali mu se daje i vrijeme da motorička kretnja koja se učila taj dan u slobodno vrijeme analizira i na taj način trajno usvoji. $\mathrm{U}$ programu škole u prirodi postoji i niz drugih aktivnosti koje se ne odnose na plivanje te je očito i manje prostora za napredak. Isto tako, zbog kratkog vremena prisiljeni smo u jednom danu obraditi znatno više nastavnih tema koje učenici očito nisu trajno usvojili i stvorili stereotip motoričkog gibanja. Učenje motornih gibanja pravi je intelektualni zadatak koji je u velikoj mjeri ovisi o psihološkim procesima pažnje, pamćenja, protok informacija i rješavanje problema ovisno o vrsti obrade podataka u središnjem živčanom sustavu (Horga, 1993). Učenje plivanja traje od percepcije, stvarajući sliku kretanja, memorije, ponavljanja, konsolidaciju kako bi potvrdili stečena znanja u različitim uvjetima (Jurak, 1999). Vidljivo je da program škole u prirodi ne daje dovoljno vremena kako bi učenici savladali sve etape motoričkog učenja koliko daje program u sklopu ljetovanja.

Iz Tablice 12. vidljivo je da je utvrđena statistički značajna razlika u napretku u ocjenama (između inicijalnih i finalnih stanja) među modelima i to u korist modela 1. Osim što je model 
1. ostvario bolje rezultate u finalnim stanjima, veći je i statistički značajan napredak u ocjenama. Hipoteza je postavljena na način da će napredak biti isti, no pokazalo se suprotno.

\section{ZAKUUČAK}

Istraživanje je provedeno s ciljem utvrđivanja kakvi se učinci mogu postići primjenom programa poduke neplivača te usporediti rezultate dobivenih kod djece koja pohađaju program u različitim uvjetima - modelima rada.

Program je proveden u dvama modelima rada koja se provode u sklopu nastave s djecom mlađe školske dobi. Prvi je model u sklopu ljetovanja i traje 14 dana u kojima su distribuirani dvadeset sati poduke neplivača. Drugi je model u sklopu škole u prirodi i provodi se prema istom programu u istoj satnici, ali koncentriranih u šest dana. Ukupan je broj ispitanika bio 201 dijete. Vrednovanje programa praćeno je skalom od jedanaest ocjena i to u inicijalnim, tranzitivnim i finalnim stanjima. Program je konstruiran sukladno najnovijim znanstvenim spoznajama i iskustvima autora i suradnika.

Djeca koja su učila plivati po modelu 1. ostvarila su značajan napredak u odnosu na inicijalno stanje. Samim tim možemo zaključiti da je model u sklopu ljetovanja pogodan za poduku neplivača te se može prihvatiti prva hipoteza. Naime, nakon provedenog programa i finalnog testiranja, raspon ocjena je od 6 do 11, a najveći postotak čini ocjena 11 (51,51\%) koja karakterizira plivača početnika. Najveći broj, njih 37, napredovalo je za 6 ocjena (37,37\%), samo jedan za 11 i jedan za 2 (1,01 \%) što opisuje uspješnost programa.

Djeca koja su učila plivati prema modelu 2. ostvarila su također značajan napredak u odnosu na inicijalno stanje. Možemo zaključiti da je model u sklopu škole u prirodi pogodan za poduku neplivača te se može prihvatiti druga hipoteza. Nakon provedenog programa i finalnog testiranja, raspon ocjena je od 3 do 11, a najveći postotak čini ocjena 11 (44,11 \%). Kao i u modelu 1. bilježimo znatan broj učenika koji su se pomaknuli za četiri i više ocjena, ali u ovom modelu njih 35 nije zadovoljilo taj kriterij.

Između rezultata u finalnim mjerenjima postoji statistički značajna razlika te možemo prihvatiti treću hipotezu. Kako u inicijalnim stanjima nije bilo statistički značajne razlike, zaključujemo da je program 1 . dao bolje rezultate u poduci neplivača. $U$ finalnom ocjenjivanju uočava se statistički značajna razlika u korist modela1.

Postoji statistički značajna razlika u napretku između inicijalnih i finalnih stanja između modela i to u korist modela 1 . Program ljetovanja ostvario je bolji napredak u odnosu na program škole u prirodi te se može odbaciti četvrta hipoteza.

Rezultati dobiveni provedenim istraživanjem pokazali su da oba programa daju dobre rezultate i prigodni su za poduku neplivača. Prednost dajemo modelu 1. odnosno poduci neplivača u sklopu ljetovanja. Model 2. poduke neplivača u sklopu škole u prirodi radi se u šest dana i očito mu nedostaje vremenskog prostora za još kvalitetniju provedbu. Kako je riječ o programima koji se provode u svim sredinama, neobično je bilo važno utvrditi učinkovitost programa te detektirati uspješnosti pojedinih modela. 


\section{LITERATURA}

Andrew, G. M., Becklare, M. R., Guleria, J. S. i Bates, D. V. (1972). Heart and lung functions in swimmers and nonathletes during growth. Journal of Applied Physiology, 32(2), 245-251.

Bednarik, J., Novak, H. i Kapus, V. (1990). Projektna metoda, drugačna pot do znanja plivanja. U: Kapus, V. (ur.), Zbornik del III Jug. Posveta o učenju plavanja in varnosti pred utapljanjem. (str. 16-18). Portorož, Ljubljana: Fakulteta za šport.

Cuurteix, D., Obert, P., Lecoq, A. M., Guenon, P. i Koch, G. (1997). Effect of intesive swimming training on lung volumes, airway resistance and on the maximal expiratory flow-volume relationship in prepubertal girls. Journal of Applied Physiology , 76(3), 264-269.

Findak, V. (2002). Oprema i sredstva u funkciji obuke neplivača. Sport za sve: glasnik Hrvatskog saveza sportske rekreacije, 31, 4-7.

Findak, V. i Delija, K. (2001). Tjelesna i zdravstvena kultura u predškolskom odgoju. Zagreb: Edip.

Findak, V. (1981). Učimo djecu plivati. Zagreb: Školska knjiga.

Grčić-Zubčević, N. (1996). Efikasnost različitih programa te mogući čimbenici uspješnosti učenja plivanja. Doktorska disertacija, Sveučilište u Zagrebu, Fakultet za fizičku kulturu, Zagreb.

Grčić-Zubčević, N. (1996). Socijalni status okruženja djece neplivača. U: V. Findak (ur.), Zbornik radova 5. Ljetne škole pedagoga fizičke kulture Republike Hrvatske (str. 48-50). Rovinj: Savez pedagoga fizičke kulture Hrvatske.

Grčić-Zubčević, N. i Rastovski, D. (2009). Plan i program obuke neplivača u sklopu škole u prirodi, verificiran od strane Agencije za odgoj i obrazovanje i Ministarstva znanosti prosvjete i sporta.

Grčić-Zubčević, N. i Marinović, V. (2009). 300 igara u vodi za djecu predškolske dobi. Zagreb: Intergrafika.

Grčić-Zubčević, N., Rastovski, D. i Malečić, Z. (2010). Usvojenost znanja plivanja. Centar za edukaciju Gradskog društva Crvenog križa Orahovica.

Grčić-Zubčević, N., Čulina, M. i Leko G. (2002). Analiza napredovanja učenja plivanja neplivača. U: V. Findak (ur.), Zbornik radova 11. Ljetne škole kineziologa Republike Hrvatske, (str. 57-59). Rovinj: Hrvatski kineziološki savez.

Grčić-Zubčević, N. (1990). Utjecaj nekih dimenzija specijalne motorike na efikasnost učenja plivanja djevojčica predškolskog uzrasta. U: V. Kapus (ur.), Zbornik del III. Jug. posveta o učenju plavanja in varnosti pred utapljanjem (str. 67-71.). Portorož, Ljubljana: Fakulteta za telesno kulturo.

Horga, S. (1993). Psihologija sporta. Zagreb: Fakultet za fizičku kulturu.

Jurak, G. (1999). Primerjava treh programov učenja plavanja 8 - do 9-letnih učenci z vidika znanja plavanja. Magistarsko delo. Ljubljana: Univerzav Ljubljani, Fakulteta za šport.

Jurak G., Kapus, V., Strel, J. i Kovač, M. (2001). Comparison of three breaststroke swimming instructiom programmes for 8 to 9 year old children. Kineziology, 33(2), 182-188.

Jurak, G. i Kovač, M. (2002). Pomen znanja plavanja. U: G. Jurak (ur.) Učenje plavanja v Sloveniji 1994-2000. Ljubljana: Zavod za šport Slovenije.

Kaljanac, J., Kazazović, F., Božur, Z., Burić, Z., Vidović, N. i Đorđević, N. (1988). Utjecaj inicijalnog stanja na tok i konačne efekte obrazovnog procesa obuke plivanja odraslih. Zbornik radova II. Jugoslavenskog savjetovanja o obuci neplivača.

Kapus, V., Šink, I. i Ambrožič, F. (1981). Povezanost dimenzij osnovne in specialne motorike ter morfoloških in funkcionalnih dimenzij z uspešnostjo $v$ športnem plavanju 10 do 12-letnih plavalcev obeh spolov. Ljubljana: Visoka šola za telesno kulturo, Inštitut za kineziologijo.

Kapus,V. i sur. (2002). Plavanje, učenje. Ljubljana: Fakulteta za šport, Institut za šport.

Kazazović, B. i Hadžikanudić, M. (1988). Zakonomjernosti i specifičnost procesa obuke plivanja djece osnovnog školskog uzrasta. Zbornik radova II. Jugoslavenskog savjetovanja o obuci neplivača (str. 55-59.).

Leko, G. (1990). Utjecaj nekih mjera antropometrije na efikasnost učenja plivanja djece školskog uzrasta. U: V. Findak (ur.), Zbornik radova 2. Republičkog savjetovanja o obuci neplivača (str. 810.), Poreč. 
Lorger, M. i Prskalo, I. (2010). Igra kao početni oblik treninga brzine u predškolskoj dobi. U: I. Jukić, C. Gregov, S. Šalaj, L. Milanović, T. i Trošt-Babić (ur.), 8. godišnja međunarodna konferencija „Kondicijska priprema sportaša“ (str. 473-476). Zagreb: Kineziološki fakultet.

Malečić, Z., Rastovski, D. i Grčić-Zubčević, N. (2010). Metodički organizacijski oblici rada sučenicima osnovne škole. Sport za sve: glasnik Hrvatskog saveza sportske rekreacije, 16-19.

Matković, J. i Tačić, B. (1988). Istraživanje uspešnosti obuke neplivača u plitkoj i dubokoj vodi na populaciji studenata Beogradskog univerziteta. U Zbornik radova II. Jugoslavenskog savjetovanja o obuci neplivača. Pančevo.

Mirošević, I. (2002). Normativna regulacija u obuci plivanja - djelatnost i objekti. Sport za sve: glasnik Hrvatskog saveza sportske rekreacije, 31, 16-19.

Okičić, T. i Aleksandrović, M., (2008). Utecaj različitih programa obuke neplivača na usvojenost znanja plivanja (znanstveno-stručni projekt).

Pastuović, N. (1991). Osnove psihologije edukacije. U: V. Kolesarić, M. Krizmanić i B. Petz (ur.), Uvod u psihologiju. Zagreb: GZH.

Popov, I. (1998). Plavane. Sofija: NSA - Pres.

Prskalo, I. (2007). Kineziološki sadržaji i slobodno vrijeme učenica i učenika mlađe školske dobi. Odgojne znanosti, 9(2), 319-331.

Prskalo, I., Babin, J. i Bavčević, T. (2010). Metodički organizacijski oblici rada i njihova učinkovitost u kineziološkoj edukaciji. Metodika: časopis za teoriju i praksu metodikâ u predškolskom odgoju, školskoj $i$ visokoškolskoj izobrazbi, 11(20), 34-43.

Rastovski, D., Tomac, Z., Šumanović, M. i Filipović,V. (2011). Parents' Motivation For Choosing Swimming As A Sport Activity For Their Child. U: Mikalački, M. i Bala, G. (ur.), 2nd International Scientific Conference "Exercise and Quality of Life" (str. 245-250). Novi Sad : Faculty od Sport and Physical Education.

Sir Woolley, L. (1966). Počeci civilizacije. Zagreb: Naprijed.

Šajber, D., Kapus, V., Bednarik, J., Štrumbelj, B. i Kapus, J. (2000). Fredov program učenja plavanja (Fred's swimming program). U: R. Pišot i V. Štemberger (ur.), Otrok v gibanju : zbornik prispevkov (str. 414-418). Ljubljana: Pedagoška fakulteta.

Šajber, D. i Vidovič, M. (2004). Usporedbe različitih metoda učenja plivanja. Sport za sve, glasnik Hrvatskog saveza sportske rekreacije, 22(39), 46-48.

Volčanšek, B., Matković, I. (1990). Utjecaj nekih dimenzija specijalne motorike na efikasnost učenja plivanja dječaka predškolskog uzrasta. U: V. Kapus (ur.), Zbornik del III. jug. posveta o učenju plavanja in varnosti pred utapljanjem (str. 57-61). Ljubljana: Fakulteta za telesno kulturo.

\title{
Model of Work - a Factor in the Success of swimming Lessons
}

\begin{abstract}
In order to determine the effectiveness of particular models of teaching non-swimmers, and comparisons of the tested population of 201 children aged 9 to 11 years. The sample was divided into two subgroups, where the children were taught how to swim by the same program, but in a variety of models. The first model was a model of teaching non-swimmers in the summer and for a period of 14 days, while the other model implemented within the school program but in six days. To determine the effectiveness of these models a statistical software package STATISTICA version 6.0 (StatSoft Inc.., Tulsa, OK, USA). To view the distribution of variables were used frequency tables, showing characteristic distribution with arithmetic mean (AM), standard deviation (SD), $95 \%$ confidence interval for AS $(95 \% \mathrm{Cl})$, median (M), interquartile range (IQR), range and the coefficients of symmetry (Skewness) and flatness (kurtosis) distribution. Normality of distribution of individual variables tested by the Kolmogorov-Smirnov test and was found not to follow the same. To compare the progress of the groups used the Wilcoxon Matched Pairs Test, and for comparison between groups by Mann-Whitney $U$ test (for comparison of the initial and final measurements of the difference between the final and initial measurements). As a statistically significant $P$ value was $<0.05$. After research showed that both programs yielded significant advancements but also found that the type 1 and non-swimmers under the instruction more efficient holiday.
\end{abstract}


Keywords: teaching non-swimmers, summer camps, schools in nature, models of work

\section{Arbeitsmodell - erfolgsfaktor im Scwimmunterricht}

Zusammenfassung: Diese Studie wurde durchgeführt, um die Effektivität einzelner Modelle von Nichtschwimmerkursen festzustellen und dieselben zu vergleichen. Dabei wurden 201 Kinder im Alter zwischen 9 und 11 Jahren getestet. Die Stichprobe wurde in zwei Unterstichproben unterteilt, in denen die Kinder nach dem gleichen Programm schwimmen lernten, jedoch nach unterschiedlichen Arbeitsmodellen. Das erste Modell war ein Nichtschwimmerkurs im Rahmen eines 14-tägigen Sommerurlaubs, während das andere Modell im Rahmen eines 6-tägigen Schullandheimaufenthaltes durchgeführt wurde. Um die Effektivität der beschriebenen Modelle festzustellen wurde die Statistik-Software STATISTICA Version 6.0 (StatSoft Inc., Tulsa, OK, USA) benutzt. Die Normalität der Distribution einzelner Variablen wurde mittels Kolmogorow-Smirnow-Test geprüft und es wurde festgestellt, dass sie nicht die gleiche befolgen. Zum Vergleich des Fortschritts in den einzelnen Gruppen wurde der Wilcoxon-Vorzeichen-RangTest angewendet, und für den Vergleich zwischen den Gruppen, d.h. zum Vergleich der Anfangs- und Endmessung, sowie des Unterschieds zwischen der Anfangs- und Endmessung, diente der Mann-Whitney$\mathrm{U}$-Test. Als statistisch signifikanter Wert wurde $\mathrm{P}<0,05$ verwendet. Die Befunde dieser Untersuchung zeigen, dass beide Modelle gute Ergebnisse aufweisen und sich zum Training von Nichtschwimmern eignen. Allerdings ziehen wir Modell 1, bzw. den Nichtschwimmerkurs im Rahmen eines Sommerurlaubs, vor, da es Modell 2 im Rahmen eines 6-tägigen Schullandheimaufenthaltes an Zeit für eine bessere Durchführung mangelt. Da es sich hierbei um Programme handelt, die in allen Regionen durchgeführt werden, war es von großer Bedeutung die Effektivität der Programme und den Erfolg einzelner Modelle zu ermitteln.

Schlüsselwörter: Nichtschwimmerkurse, Sommerurlaub, Schullandheimaufenthalt, Arbeitsmodelle 